\title{
Relation of Dietary Habbits and Weaning with Nutritional Status of Children
}

\author{
${ }^{1}$ Enda Silvia Putri, ${ }^{1}$ Siti Maisyaroh Fitri Siregar, ${ }^{1}$ Arfah Husna, ${ }^{1}$ Marniati, ${ }^{1}$ Darmawan \\ ${ }^{1}$ Faculty of Public Health, Universitas Teuku Umar, Aceh, Indonesia \\ Coresponding author: Enda Silvia Putri, e-mail: endasilviaputri@utu.ac.id \\ Co-author : SMFS: sitimasisyaroh@utu.ac.id, AH: arfahhusna@utu.ac.id, MM: marniati@utu.ac.id, DD: \\ darmawan@utu.ac.id \\ Submitted: 16/09/2020 Revised: 02/10/2020 Accepted: 19/10/2020 Published online: 21/10/2020
}

doi: https://doi.org/10.35308/j-kesmas.v7i2.2716 How to cite this article: Putri, E. S., Siregar, S. M. F., Husna, A., Marniati, M., \& Darmawan, D. (2020). Relation of Dietary Habbits and Weaning with Nutritional Status of Children. J-Kesmas: Jurnal Fakultas Kesehatan Masyarakat (The Indonesian Journal of Public Health), 7(2), 90-95.

\begin{abstract}
Background of the problems that occurred at the Mereubo Health Center of 114 toddlers in Peunaga Cut Ujong Village there were 3 under five malnourished toddlers, 111 under five with good nutrition status, and in Meureubo village there were 2 under five underfives and 139 underfives with good nutrition status. The purpose research was looked relation of dietary habbits and weaning with nutritional status of children. The research method is analytic survey with cross sectional survey design. The population in this study were all children aged 9-59 months in Peunaga Cut Ujong Village and Meureubo Village, Meureubo District, West Aceh Regency with 255 toddlers, and use formula solvin the sample was 72 toddlers with technic sample was simple random sampling, and analysis used chi-square-test. The results showed an association of dietary habbits (P.Value $0.015<0.05$ and OR value $=0.067)$, as well as the relationship of weaning $(\mathrm{P}$. Value $0,000<0.05$ and $\mathrm{OR}$ value $=$ 17.0) with the nutritional status of children under five in the Village Peunaga Cut Ujong, then there is a relationship between dietary habbits $(\mathrm{P}$. Value $0.011<0.05$ and $\mathrm{OR}$ value $=0.135)$ and the relationship between weaning $(\mathrm{P}$. Value $0.001<0.05$ and OR value $=16.7$ ) with the nutritional status of children in Meureubo Village. The research conclusion was relationship weaning was stronger than dietary habbits with nutrional status. The suggestions to the puskesmas provide understanding to mothers about the importance of eating patterns and provide exclusive breastfeeding and breastfeeding for two to toddlers, so that toddlers obtain nutritional status and growth development properly.
\end{abstract}

Keywords: Dietary Habbits, Weaning, Nutritional Status.

\section{Introduction}

Toddler age is a period of very rapid growth and development. Therefore, the toddler age group needs to get attention, because it is a group that is prone to malnutrition. To overcome the problem of nutritional deficiencies that occur in the toddler age group needs to be held Recovery Feeding (PMT) recovery. PMT for children aged 7-24 months is included as an addition, not as a substitute for the main daily food. Good nutritional status is one of the determining factors in the success of health development which is basically an inseparable part of overall national development. Good nutritional status can be obtained by providing sufficient food and a balanced diet according to their respective ages. (Ditjen Bina Gizi dan Kesehatan, 2015)

Based on the results of Purwani research (2013) Based on the results of this study, the value of $\mathrm{p}$ value is $0,000(\mathrm{p}<0.05)$, so it can be concluded that there is a significant relationship between the relationship between feeding patterns and nutritional status in children aged 1 to 5 years in the village
Kabunan Taman Kecamatan Pemalang Regency.(Purwani, 2013)

Toddler life, the start of the weaning process is the beginning of a big change for toddlers and mothers. During pregnancy and post-birth, the relationship gradually weakens (Newman, 2008 in Hasinuddin, 2013. (Hasinuddin, 2018). The decision to stop breastfeeding is the choice of each mother. Weaning age is usually 2 years, but some are up to 4 years or more. According to some studies the composition of breast milk continues to change until a child is 2 years old and still contains important nutrients that build a child's immune system. At certain ages toddlers must be removed from mother's milk or weaned. However, the weaning process is also not easy. There is a mother factor, there is also a toddler factor itself. Many mothers get confused when confronted with weaning their toddlers. Especially what age is right for weaning. Sometimes mothers feel guilty and feel sorry for their toddlers because they have to stop breastfeeding (Reiss, 2008 in Hasinuddin, 2013). 
Actually in other parts of the world, breastfeeding until toddlers aged 2 or 4 years is a natural thing the World Health Organization (WHO) recommends weaning done after toddlers aged 2 years (WHO, 2005 in Hasinuddin, 2013).

The Research of Rahim, 2014 With used Survey method in infants aged 7-59 months in the region of Leuwimunding health center amounts 200 samples, using cluster random sampling. The results showed the nutritional status of toddler were classified as underweight as $31.40 \%$, Unfavorable practice of toddler feeding as $43.80 \%$, The rate of energy consumption is not good for toddler as much as $60.30 \%$, and the rate of protein consumption wass less good in $54.60 \%$ of toddler. The conclusions, factors associated with underweight nutritional status in infants aged 7-9 months were toddler feeding, level of energy consumption, and protein toddlers.(Rahim, 2014)

Based on data obtained from the Aceh Provincial Health Office (2012) in Yana (2014) of 4,604 babies, from the results of research conducted it is known that 187 babies died in vulnerable time per year in Aceh. The number of babies given exclusive breastfeeding was 546 people (11.9\%).(Yana dan Ahmad, 2014)

Based on the Health Profile of Aceh Province in 2017, in Aceh Province found underfives with malnutrition of 1,543 people and malnutrition of 20,248 people (Aceh Health Office, 2017). Whereas in the District of West Aceh with a total of 13,747 children under five overall, under this number 810 cases of malnutrition were obtained.(Dinas Kesehatan Provinsi Aceh, 2017)

While in the Meureubo Community Health Center area there were 2043 children under five, of whom 17 were found to be malnourished and 2 underfives with malnutrition cases (Toddler Figures with Malnutrition) (Meureubo Health Center in 2018).(Puskesmas Meureubo, 2018). While in the Johan Pahlawan Community Health Center there were 9 undernutrition cases out of 4174 children under five, this was a comparison, that the Meureubo Health Center was classified as undernourished (Community Health Center,Johan Pahlawan, 2018).(Puskesmas Johan Pahlawan, 2018)
While weaning data from the Meureubo Community Health Center, the data was obtained at the time of the implementation of Posyandu in each village, where there were 1081 toddlers who were weaned from the total number of toddlers, 2043 toddlers. From the total number of children under five measured / weighed 1,772 , then from all toddlers there were 1748 toddlers, 17 toddlers, 2 toddlers and 5 toddlers with over nutrition.(Puskesmas Meureubo, 2018)

While seen from the research site that Peunaga Cut Ujong Village, there were 114 toddlers as many as five toddlers, from all of these toddlers, there were underweight nutritional status of 3 toddlers and good nutritional status of 111 toddlers. While in the village of Meureubo the number of toddlers is 141, of which there are 2 cases of malnutrition and 139 underfives. For weaning data, where 58 toddlers who have been weaned in Peunaga Cut Ujong Village are 58 toddlers out of 114 toddlers and in Meureubo village 98 toddlers who have been weaned from 141 toddlers.

\section{Materials and Methods}

Analytical Survey research methods with Cross Sectional Design with the aim of seeing the relationship between eating patterns and weaning with the nutritional status of children under five in Peunaga Cut Ujong Village and Meureubo Village, Meureubo District, West Aceh Regency. The population in this study were all children under five years old aged 9-59 months in Peunaga Cut Ujong Village and Meureubo Village, Meureubo District, West Aceh Regency with 255 toddlers and obtained samples using slovin formula as many as 72 toddlers with the sampling technique carried out using Simple Random Sampling. The analysis data used chisquare-tes and tools SPSS 22.(Notoatmodjo. S., 2015).

\section{Results}

\section{The Relationship Dietary Habbits With Nutritional Status}

Based on the results of bivariate analysis using the chi-square test, the results obtained as in tables 1 and 2. 
Table 1. Relationship Dietary Habbits with Nutritional Status of Toddlers in Peunaga Cut Ujong Village, Meureubo District, West Aceh Regency.

\begin{tabular}{|c|c|c|c|c|c|c|c|c|}
\hline \multirow{3}{*}{ dietary habit } & \multicolumn{4}{|c|}{ Nutritional status } & \multirow{2}{*}{\multicolumn{2}{|c|}{ Total }} & \multirow{3}{*}{$\begin{array}{c}P \\
\text { Value }\end{array}$} & \multirow{3}{*}{$O R$} \\
\hline & \multirow{2}{*}{\multicolumn{2}{|c|}{ good }} & \multirow{2}{*}{\multicolumn{2}{|c|}{$\begin{array}{l}\text { not } \\
\text { geod }\end{array}$}} & & & & \\
\hline & & & & & $\mathbf{n}$ & $\%$ & & \\
\hline good & 1 & 11,1 & 8 & 88,9 & 9 & 100 & & \\
\hline not good & 15 & 65,2 & 8 & 34,8 & 23 & 100 & $(0,015)$ & $(0,067)$ \\
\hline Total & 16 & 50,0 & 16 & 50,0 & 32 & 100 & & \\
\hline
\end{tabular}

Based on Table 1. shows that of the 9 respondents who gave a good diet with a good nutritional status of toddlers as many as 1 person $(11.1 \%)$ and as many as $8(88.9 \%)$ people with poor nutritional status, whereas of 23 respondents who provide poor diet with good nutritional status of 15 children $(65.2 \%)$ and as many as $8(34.8 \%)$ people with poor nutritional status.

Table 2. Relationship Dietary Habbits with Nutritional Status of Toddlers in Meureubo Village, Meureubo District, West Aceh Regency.

\begin{tabular}{|c|c|c|c|c|c|c|c|c|}
\hline \multirow{3}{*}{ Dietary habit } & \multicolumn{4}{|c|}{ Nutritional status } & \multirow{2}{*}{\multicolumn{2}{|c|}{ Total }} & \multirow{3}{*}{$\begin{array}{c}P \\
\text { Value }\end{array}$} & \multirow{3}{*}{ OR } \\
\hline & \multicolumn{2}{|c|}{ Good } & \multicolumn{2}{|c|}{ Poorly } & & & & \\
\hline & $\mathrm{n}$ & $\%$ & $\mathrm{n}$ & $\%$ & $\mathrm{n}$ & $\%$ & & \\
\hline Good & 4 & 23.5 & 13 & 76,5 & 17 & 100 & & \\
\hline Poorly & 16 & 69.6 & 17 & 30,4 & 23 & 100 & $(0,011)$ & $0,135)$ \\
\hline Total & 20 & 50,0 & 20 & 50,0 & 40 & 100 & & \\
\hline
\end{tabular}

Based on Table 2. above shows that of the 17 respondents who gave good eating patterns with good nutritional status of toddlers as many as 4 people $(23.5 \%)$ and as many as $13(76.5 \%)$ people with underfive nutritional status were poor, while of 23 respondents those who provided poor diet with good nutritional status of toddlers were 16 people $(69.6 \%)$ and $17(30.4 \%)$ people with poor toddler nutritional status.

\section{Relationship Weaning with Nutritional Status}

Based on the results of bivariate analysis using the chi-square test, the results obtained as in tables 3 and 4

Table 3. Relationship Weaning with Nutrition Status in Toddlers in Peunaga Cut Ujong Village, Meureubo District, West Aceh Regency.

\begin{tabular}{|c|c|c|c|c|c|c|c|c|}
\hline \multirow{3}{*}{ Weaning } & \multirow{2}{*}{\multicolumn{4}{|c|}{\begin{tabular}{cc}
\multicolumn{2}{c}{ Nutritional Status } \\
Good
\end{tabular}}} & \multirow{2}{*}{\multicolumn{2}{|c|}{ Total }} & \multirow{3}{*}{$\begin{array}{c}P \\
\text { Value }\end{array}$} & \multirow{3}{*}{$O R$} \\
\hline & & & & & & & & \\
\hline & $\mathrm{n}$ & $\%$ & $\mathrm{n}$ & $\%$ & $\mathrm{n}$ & $\%$ & & \\
\hline Good & 16 & 94.1. & 1 & 5,9 & 17 & 100 & & \\
\hline Poorly & 0 & 0 & 15 & 100,0 & 15 & 100 & $(0,000)$ & $(17,0)$ \\
\hline Total & 16 & 50,0 & 16 & 50,0 & 32 & 100 & & \\
\hline
\end{tabular}

Based on Table 3. shows that of the 17 respondents who did good weaning in toddlers with good nutritional status of toddlers as many as 16 people $(94.1 \%)$ and as many as $1(5.9 \%)$ people with poor toddler nutritional status categories, whereas of
15 respondents who did not wean less well on toddlers with good nutritional status of toddlers as many as 0 people $(0 \%)$ and as many as $15(100.0 \%)$ people with poor toddler nutritional status categories.

Table 4. Relationship Weaning with Nutrition Status in Toddlers in Meureubo Village, Meureubo District, West Aceh Regency.

\begin{tabular}{|c|c|c|c|c|c|c|c|c|}
\hline \multirow{3}{*}{ Weaning } & \multicolumn{4}{|c|}{ Nutritional status } & & & \multirow{3}{*}{$\begin{array}{c}P \\
\text { Value }\end{array}$} & \multirow{3}{*}{$O R$} \\
\hline & \multicolumn{2}{|c|}{ good } & \multicolumn{2}{|c|}{ poorly } & \multicolumn{2}{|c|}{ Total } & & \\
\hline & $\mathrm{n}$ & $\%$ & $\mathrm{n}$ & $\%$ & $\mathrm{n}$ & $\%$ & & \\
\hline Good & 18 & 720 & 7 & 28,0 & 25 & 100 & & \\
\hline poorly & 2 & 13,3 & 13 & 86,7 & 15 & 100 & $(0,001)$ & $(16,7)$ \\
\hline Total & 20 & 50,0 & 20 & 50,0 & 40 & 100 & & \\
\hline
\end{tabular}


Based on Table 4. above shows that of the 25 respondents who did good weaning in toddlers with a good nutritional status of toddlers as many as 18 people $(72.0 \%)$ and as many as $7(28.0 \%)$ people with a toddler nutritional status category were not good, whereas of 15 respondents who did poor weaning in infants with good nutritional status as many as 2 people $(13.3 \%)$ and as many as $13(86.7 \%)$ people with poor nutritional status categories.

\section{Discussion}

\section{The Relationship Dietary Habbits with Nutritional Status}

From the Chi-Square test results obtained P.Value value of $0.015<0.05$ until it can be concluded that there is a relationship between eating patterns with the nutritional status of children under five in Peunaga Cut Ujong Village, Meureubo District, West Aceh Regency. From the results of the odds ratio (OR), a value of 0.067 means that someone who gives a good diet to toddlers has an opportunity for toddlers with good nutritional status 0.067 times greater than someone giving a poor diet.

From the Chi-Square test results obtained P.Value value of $0.011<0.05$ until it can be concluded that there is a relationship between eating patterns with the nutritional status of children under five in Meureubo Village, Meureubo District, West Aceh Regency. From the results of the odds ratio (OR), the value obtained is 0.135 which means that someone who gives a good diet to toddlers has an opportunity for toddlers with good nutritional status 0.135 times greater than someone giving a poor diet.

According to Almatsier (2017) that a good diet contains food sources of energy, a source of building substances and a source of regulating substances, because all nutrients are needed for body growth and maintenance as well as brain development and work productivity, and eaten in sufficient quantities according to need. Toddlers who have a good diet and are given by their parents certainly do not have a good nutritional status, this we can see from the results of the study. Therefore, a good diet for toddlers really needs to be considered by parents because it will guarantee the nutritional status of a good toddler later.(Almatsier, 2017)

Based on the results of the study, a very basic problem is the lack of good dietary arrangements for toddlers by their parents. The solution to this problem is that parents should be even better at paying attention to their toddler's diet and there are balanced dietary arrangements for toddlers.
This is in line with Cindar's research (2015) which states that there is a tendency for good energy consumption levels to have good nutritional status. Chi-square test results of 13.216 with a significance $<0.01<0.05$ which means there is a positive relationship between the level of energy consumption with the nutritional status of children under five.(Cindar, 2015)

Meanwhile Ade (2016) also explained that the purpose of giving the best food to infants and children is to provide for their needs in order to maintain health, quickly recover the body's condition if sick, carry out various types of activities, maintain physical and psychometric growth and development. In addition, so that they are educated good habits about food and like the food that is needed. (Ade. M., 2016)

Vyas research, 2014 in India stated that weaning did not significantly affect the nutritional status of children under five, but different from eating habits after weaning turned out to affect the nutritional status of children under five. . The food that is given is sometimes too soft, runny, even too ripe so that it affects the quality of food given to the toddler.(Vyas, Shaili., Kandpal, S. D., Semwal, Jayanti., Chauhan, Sandhya., Nautiyal, 2014)

Ishmah Research, 2018 related to stunting which was one of the effects of lack of nutritional intake and was an indicator of poor nutritional status, the results of the study stated that there was a relationship between weaning and the incidence of stunting in infants $(\mathrm{p}=0,000)$.(Aprilia Maulidah Ishmah, Agustin Syamsianah, 2017)

\section{The Relationship Weaning with Nutritional Status}

From the Chi-Square test results obtained P.Value value of $0,000<0.05$ until it can be concluded that there is a relationship between weaning and nutritional status of children under five in Peunaga Cut Ujong Village, Meureubo District, West Aceh Regency. From the odds ratio (OR), a value of 17.0 means that someone who does good weaning for toddlers has a 17.0 times better chance for toddlers compared to someone who does poor weaning.

From the Chi-Square test results obtained P.Value value of $0.001<0.05$ until it can be concluded that there is a relationship between weaning and the nutritional status of children under five in Meureubo Village, Meureubo District, West Aceh Regency. From the results of the odds ratio (OR), the value obtained is 16.7 which means that 
someone who does weaning well in infants has a 16.7 times greater chance for toddlers with good nutritional status compared to someone doing weaning less well.

Toddlers who are weaned earlier by parents who are under the age of 2 years will surely experience poor nutritional status, because the amount of breast milk intake is not optimal which is the best food or intake for infants up to the age of 2 years. Based on the results of the research, a very basic problem is the lack of mother's knowledge of the importance of breastfeeding for toddlers to the maximum that is for 2 years, as well as the density of the mother's busyness in working to make the weaning process carried out quickly ie in infants under 2 years. The solution to this problem is that mothers should prioritize the interests of children, namely babies, especially in the case of exclusive breastfeeding so that the growth and development of babies can be optimal.

The above research results are supported by the results of Hasinuddin's research (2013), that there is an effect of weaning on the nutritional status of toddlers in Karang Bili, East Java.(Hasinuddin, 2018)

Pambudi Research Results, 2017 states that the practice of early weaning by toddlers mothers affects the nutritional status of their toddlers. Masruro's research states that there was a correlation of weaning on the nutritional status of children under five years of age 6-24 months (Pvalue 0.027 $<<\alpha$ : 0.05). (Pambudi, Joko., Christijani, 2017)

The results of hastuti research, 2016 in Wonogori on 40 children aged 25-36 months stated that there was a relationship between weaning and parenting for toddlers mothers and their toddler nutritional status by obtaining grades ( $\mathrm{P}$ vlue $<\alpha$ : 0.05 ). The same statement was also obtained from Yunaidah's research results in Batang, There was a relationship between maternal behavior in feeding and energy-sufficiency level of protein nutritional status.(HASTUTI, 2016)

The Masyudi Research, 2019 in Muara Batu District, North Aceh District, Analysis using Chisquare test. The results show the relationship between parenting $(\mathrm{p}=0,021 ; \mathrm{OR}=3,6)$ and weaning age $(\mathrm{p}=$ $0,042 ; \mathrm{OR}=3,5)$ with the nutritional status of toddlers. In conclusion, poor parenting and the fast age of weaning have an impact on the high number of cases of malnutrition in children under five in Muara Batu District, North Aceh.(Masyudi, Mulyana, \& Rafsanjani, 2019).

\section{Conclusion}

From the results of the discussion that has been explained can be concluded was :

1. There was the relationship dietary habbits (P.Value $0.015<0.05$ and $\mathrm{OR}$ value $=0.067$ ), and weaning (P.Value 0,000<0, 05 and the value $\mathrm{OR}=17.0$ ) with the nutritional status of children under five in Peunaga Cut Ujong Village, Meureubo District, West Aceh Regency.

2. There was the relationship dietary habbits (P.Value $0.011<0.05$ and $O R$ value $=0.135)$, and weaning (P.Value $0.001<0.05$ and the value OR $=16.7$ with the nutritional status of children under five in Meureubo Village, Meureubo District, West Aceh Regency.

\section{Acknowledgement}

The researcher would like to thank the mothers with toddlers who have participated in the research (Mothers with domisily in Meureubo, Community Health Center Meureubo).

\section{Author Contribution and Competing Interest}

All of the authors contributed in collecting and analyzing the data, including preparing the manuscript. The first author acted as the chief researcher and as the corresponding author. The second, the third, and the forth author as members of researcher helping the first author in collecting and analyzing the data. There was no competing interest to the conduct of this study.

\section{Publisher's Note}

J-Kesmas: Jurnal Fakultas Kesehatan Masyarakat (Indonesia Journal of Public Health) remains neutral with regard to jurisdictional claims in published institutional affiliation.

\section{References}

Ade. M. (2016). Peranan Pangan dan Gizi untuk Kualitas Hidup. Jakarta: PT Gramedia Pustaka Utama.

Almatsier, S. (2017). Prinsip Dasar Ilmu Gizi. Jakarta: PT. Gramedia Pustaka Utama.

Ishmah, A., Agustin Syamsianah, Y.N. S. U. (2017). Hubungan Berat Bayi Lahir, Usia Penyapihan dan Tingkat Kecukupan Energi Dengan Kejadian Stunting Pada Balita Di Desa 
Jatisono, Kecamatan Gajah, Kabupaten Demak. Thesis. Universitas Muhammadiyah Semarang.

Cindar, B. (2015). Pengaruh Ibu yang Bekerja terhadap Status Gizi Anak Balita di Kelurahan Mangunjiwan Kabupaten Demak.

Dinas Kesehatan Provinsi Aceh. (2017). Profil Kesehatan Aceh Tahun 2017. Banda Aceh.

Ditjen Bina Gizi dan Kesehatan. (2015). Pemberian Makanan Tambahan. Jakarta: Depertemen RI.

Hasinuddin. (2018). Pengaruh Ketepatan Waktu Penyapihan terhadap Status Gizi Balita Usia 24-36 Bulan di Wilayah Kerja Puskesmas Bangkalan. Skripsi Sekolah Tinggi Ilmu Kesehatan Ngudia Husada Madura.

Hastuti, R. D. (2016). Hubungan Umur Penyapihan Dan Pola Asuh Makan Terhadap Status Gizi Anak Balita Usia 25-36 Bulan Di Desa Purwosari Kabupaten Wonogiri. Skripsi. Universitas Muhammadiyah Surakarta.

Masyudi, M., Mulyana, M., \& Rafsanjani, T. M. (2019). Dampak pola asuh dan usia penyapihan terhadap status gizi balita indeks BB/U. AcTion: Aceh Nutrition Journal, 4(2) : $11-116$

Notoatmodjo. S. (2015). Metodologi Penelitian Kesehatan. Jakarta: Rineka Cipta.
Pambudi, Joko., Christijani, R. (2017). Praktek Penyapihan Dini Serta Hubungannya Dengan Keadaan Sosial Ekonomi Dan Wilayah Tempat Tinggal. Jurnal Penelitian Gizi Dan Makanan, 40(2):87-94.

Purwani, dan M. (2013). Pola Pemberian Makan dengan Status Gizi Anak Usia 1 Sampai 5 Tahun Di Kabunan Taman Pemalang. 1(1): 30-36

Puskesmas Johan Pahlawan. (2018). Laporan Gizi Puskesmas Johan Pahlawan Tahun 2017. Meulaboh.

Puskesmas Meureubo. (2018). Laporan Gizi Puskesmas Meureubo Tahun 2017. Meulaboh.

Rahim, F. K. (2014). Faktor Risiko Underweight Balita Umur 7-59 Bulan. KESMAS - Jurnal Kesehatan Masyarakat, 9(2), 115-121.

Vyas, Shaili., Kandpal, S. D., Semwal, Jayanti., Chauhan, Sandhya., Nautiyal, V. (2014). Trends in Weaning Practices among Infants and Toddlers in a Hilly Terrain of a Newly Formed State of India. International Journal of Preventive Medicine, 05(06), 741-748.

Yana, R. (2014). Faktor-Faktor yang Mempengaruhi Usia Penyapihan di Desa Manyang Lancok Kecamatan Meureudu Kabupaten Pidie Jaya. Skripsi. Universitas Ubudiyah Indonesia. 